\title{
増殖型ヘルペスウイルスを用いた脸腫瘍治療
}

\author{
宮本 伸哉藤堂 具 紀
}

\section{Brain Tumor Therapy using Oncolytic Herpes Simplex Virus Vectors \\ by}

Shinya Miyamoto, M.D., and Tomoki Todo, M.D., Ph. D.

from

Department of Neurosurgery, Graduate School of Medicine, The University of Tokyo

Despite recent advances in surgical techniques, chemotherapy and radiotherapy, the poor prognoses of malignant glioma patients have not changed in the past decades. The use of oncolytic viruses is a promising new strategy for treating cancer including malignant glioma. The basic concept of oncolytic virus therapy is to kill the tumor cells via infection with replication-competent viruses such as herpes simplex virus. This concept, however, was not practical until the recent progress in genetic engineering enabled a manipulation of the viral genome to restrict the virus replication to tumor cells. Oncolytic viruses can also serve as vectors that can provide an amplified transgene delivery within the tumor. Multiple oncolytic virus vectors have been tested in clinical trials for malignant gliomas, most by direct intratumoral administration, the results of which have demonstrated the feasibility and potential of this therapeutic approach. The efficacy of oncolytic virus therapy may be enhanced by combining it with other adjuvant therapies. There remain problems to be solved which include how to obtain maximum delivery of the virus to tumor cells via systemic administration without losing a substantial amount by attachment to the vessel wall, hemodilution, filtration in the liver, and inability to pass the blood-brain barrier. Nonetheless, the development of oncolytic virus therapy may lead to a breakthrough in the treatment for malignant gliomas.

(Received July 1, 2005; accepted September 7, 2005)

Key words : oncolytic virus therapy, herpes simplex virus vectors, malignant gliomas

Jpn J Neurosurg（Tokyo） $15: 97-104,2006$

\section{はじめに}

悪性神経膠腫は，数多い悪性新生物の中において，有 病率は低いもののきわめて予後が悪く，しかも近年の画 像診断, 放射線㙩法, 化学療法等の目覚ましい進歩にも かかわらず, 治療成績の向上がほとんどみられていない. 例えば，悪性神経膠腫の代表である膠芽腫においては， 生存期間中央値（median survival time；MST）が約 12〜 14 力月, 5 年生存率が $10 \%$ 以下できわめて予後が悪い.
現在, 悪性脳腫愓に対する治療は, 手術に加えて, 化 学療法, 放射線療法を適宜併用する集学的治療が一般的 である。しかしながら, 放射線または化学療法が実際奏 効するのは悪性脳腫瘍患者のごく一部であり，多くの場 合効果は限定的である。ウイルス療法は, 脳腫瘍に限ら ず多くの悪性腫瘍において有効性が報告されており, 新 たな補助療法として期待されている。

東京大学医学部大学院医学系研究科脳神経外科 $/ \overline{\mathrm{T}} 113-8655$ 文京区本郷 7-3-1〔連絡先：宮本伸哉〕

Address reprint requests to: Shinya Miyamoto, M.D., Department of Neurosurgery, Graduate School of Medicine, The University of Tokyo, 7-3-1 Hongo, Bunkyo-ku, Tokyo 113-8655, Japan 
Oncolytic viruses

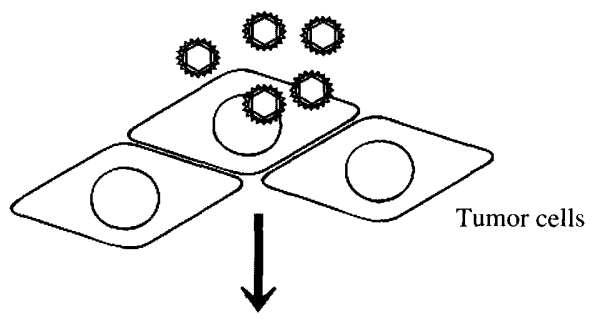

Cell destruction followed by virus spread and infection to surrounding tumor cells

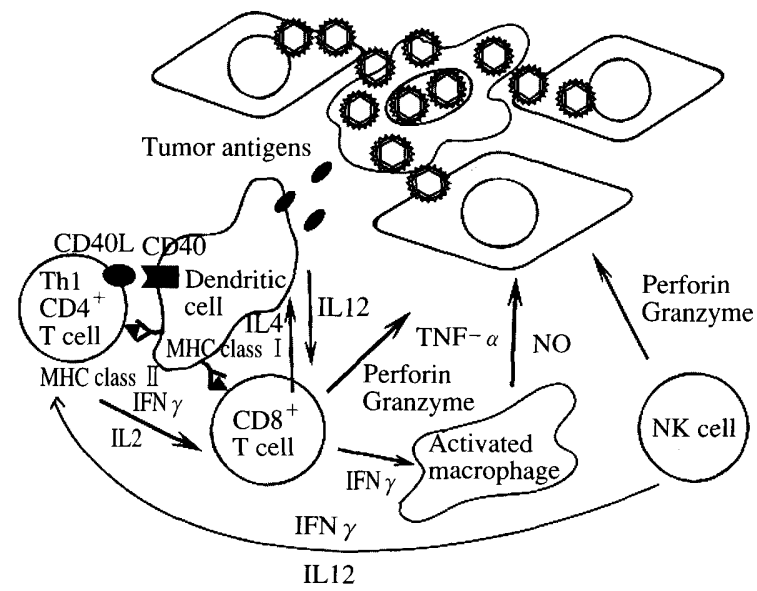

Systemic antitumor immune responses

Fig. 1 Schematic demonstrating the concept of oncolytic virus therapy

\section{ウイルス療法開発の背景}

ウイルスを悪性腫瘍の治療に応用するという発想自体 は，決して新しいものではない。すでに前世紀初頭には 急性のウイルス感染を起こした白血病患者が緩解した例 が観察されたことが契機となり7)，1950 年までにウイル スを用いた数多くの動物実験が行われた ${ }^{22)}$ 。しかし，著 明な腫瘍縮小効果が認められたものの，当時は野生型ウ イルスや継代による弱毒化ウイルス，自然に発生した変 異ウイルスを用いたため, ウイルスによる毒性が問題と なり，結局広く臨床応用されるに至らなかった。

その後, 近年のウイルスゲノムの解明や遺伝子組換え 技術等の目覚ましい進歩により，ウイルスの病原性を人 為的に制御することが可能となつた。また，癌は，癌遺 伝子の発現，癌抑制遺伝子の不活化などの遺伝子異常に より，多くの因子が関与する細胞増殖シグナルの伝達, 制御系が破綻し，結果的に無秩序な細胞増殖が生ずるこ とから発生すると考えられ，1つの因子をターゲットと しても, 汎用される治療法とはなりにくい. ウイルス療 法は，基本的には分子標的治療薬のような特定の因子を
攻撃する治療とは異なり，癌細胞に共通した性質を利用 するため，一種類のウイルスがまったく成因の異なる 種々の腫瘍に有効であり，汎用性が高い，以上のことか ら，正常組織を傷害せずに腫瘍細胞に対して直接溶解作 用を持つ増殖型ウイルスベクターの開発の研究が再び活 発となった ${ }^{18)}$. 実際，さまざまな遺伝子改変型の増殖型 ウイルスが多くの研究者により開発され，一部ではすで に臨床試験が行われ，その有效性かつ安全性が報告され ている，現在では，さらに外来治療遺伝子をウイルスゲ ノムに直接組み込むことにより，増殖型の遺伝子治療心゙ クターとしての機能も持たせ，複合的な抗腫瘍効果を目 指した研究が精力的に行われている.

\section{ウイルス療法の基本理論と抗腫瘍免疫}

元来ウイルス療法とは，増殖型ウイルスを腫瘍細胞に 感染させ，ウイルス複製に伴うウイルスそのものの直接 的な殺細胞作用により, 腫瘍を縮小させる治療法である. すなわち，ウイルス本来の複製能力を最大限に利用する ことが基本となる。

腫瘍治療用の増殖型ウイルスは，腫瘍細胞内にて複製 能力を保ちつつ，正常組織での病原性を最小限に抑える 必要がある，ヒトを自然宿主とするウイルスを用いる場 合，弱毒化野生株や自然変異株は，腫瘍細胞と正常細胞 に対する効果の差，いわゆる therapeutic window が小さ いことから，現在では遺伝子組換えウイルスが主に使用 されている。

腫瘍細胞に感染したウイルスは細胞内で複製し，その 過程で感染細胞を死滅させる，増えたウイルスは，周囲 に散らばり, 再び他の腫瘍細胞に感染し, 同様なサイク ルを繰り返す（Fig. 1）。正常組織を傷害しない機序は, ウイルスの種類により異なる。遺伝子組換え単純へルペ スウイルス I 型（HSV-1）の場合は，正常細胞にも感染 するが，正常細胞では複製できないようにウイルスゲノ ムに遺伝子操作が加えてある ${ }^{19)}$.

HSV-1 はまた, 腫瘍特異的な細胞傷害性 T 細胞活性の 増加を伴う抗腫瘍免疫も誘導する。抗腫瘍免疫が誘導さ れる機序は一般に次のように考えられている8). 腫瘍細 胞がウイルス感染と複製によって破壊されると，樹状細 胞（dendritic cell；DC）を主とするプロフェッショナル 抗原提示細胞（professional antigen presenting cell ; professional APC）により外来性蛋白として取り込まれる。 癌抗原蛋白は，蛋白分解酵素によりペプチドの断片とな り，大部分は endosome に入り，MHCクラス II 蛋白との 複合体をつくる。しかし, 一部は, 細胞質に漏出し, MHC 
クラスI 蛋白との複合体を作る。これらの複合蛋白は $\mathrm{DC}$ の細胞膜上に発現される。従来, 外来性抗原は $\mathrm{MHC}$ クラス II 抗原提示経路に入るとされていたが, この DC によるクラス I MHC 抗原提示経路はクロスプリゼン テーションと呼ばれ，近年注目されている，DC はリン パ組織（リンパ節，脾臓など）に移動して，MHCクラ ス II 蛋白複合体を $\mathrm{CD} 4^{+}$ヘルパーT リンパ球に, $\mathrm{MHC}$ クラス I 蛋白との複合体を感作 $\mathrm{CD} 8^{+} \mathrm{T}$ リンパ球に提示 する。これらのリンパ球は細胞膜上の $\mathrm{T}$ 細胞レセプター （TCR）を介してこれらを認識し, 同時に活性化される。活 性化 $\mathrm{CD} 4+$ ヘルパー T リンパ球（Th1）は主に IL-2 およ び IFN- $\gamma$ を分泌し, 感作 $\mathrm{CD} 8^{+} \mathrm{T}$ リンパ球の活性化に寄 与する。活性化した $\mathrm{CD}^{+}$の細胞傷害性 Tリンパ球 (Cytotoxic T lymphocyte；CTL)は, 腫瘍組織に移行して, 膜穿孔性蛋白であるパーフォリンと蛋白分解酵素グラン ザイムを用いる方法と Fas 分子などの death receptor を 刺激する方法の 2 つの方法で腫瘍細胞を攻撃する。ウイ ルス療法において腫瘍細胞の膜表面に発現されたウイル ス蛋白は，APCによるプロセシングを促進し，またア ジュバント効果を呈すると推測される。

一方, ナチュラルキラー（NK）細胞は，腫瘍抗原を認 識することなく, 腫瘍細胞を攻撃することができる.NK 䋖胞は多くの活性化受容体と抑制性受容体を持ち，その 両者のシグナルのバランスにより, 細胞傷害性が決定さ れる。抑制性受容体が MHC クラス I を認識するため, MHC クラス I の発現が低下している腫瘍細胞をパー フォリン，グランザイムにて攻撃する．NK 細胞は CTL と相補う形で抗腫瘍免疫を支えている。 また，周囲組織 より産生される夕イプ I IFN (IFN $\alpha, \beta)$, Th1 の産生す る IL-2, DC 等の産生する IL-12 は, NK 細胞を活性化 する，活性化 NK 細胞自身も IL-12, タイプ II IFN (IFN$\gamma$ ）を分泌し， autocrine 的に自身の活性化を維持する. さらに, IFN- $\gamma$ は, マクロファージを活性化し, 活性化 マクロファージは NO, TNF- $\alpha$ によ, 腫瘍細胞を攻撃 する. NO は腫煌細胞中の活性酸素 reactive oxygen intermediate と結合し, peroxynitrite を生成して細胞傷害性に 働くことが知られている.

\section{増殖型単純へルペスウイルス I 型 ベクターの特徴}

HSV-1 やアデノウイルスは, 腫瘍治療用として精力的 に研究されてきた代表的な増殖型ウイルスベクターであ る.いずれもウイルス遺妘子機能の解明が進み, ウイル スゲノムの操作が可能であり, 增殖型遗伝子導入ベク
ターとしても使用できる.

HSV-1 はエンベロープを有する二重鎖 DNA ウイルス に分類され，ウイルス療法に有利な以下の特徴を備えて いる。(1)強い殺細胞効果を呈する。(2)七トのあらゆる細 胞に感染可能である. (3)ウイルス生活環とゲノム配列 が解明されている. (4)アシクロビルなどの抗ウイルス薬 が存在する。(5)病原性に関連した遺伝子が解明されてお り，遺伝子操作が可能である。(6ウイルスゲノムが大き

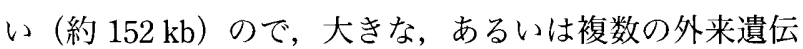
子を組み込むことができる。(7)HSV-1 に感受性を示すマ ウスやサルが存在するために, 動物で安全性や効果の前 臨床的評価を行える。(8)ヒトのゲノムに取り込まれない。

一方，不利な点としては，ゲノムサイズが大きいこと から, 従来の相同組換法で行う遺伝子操作では目的の遺 伝子組換え HSV-1 を得るのにかなりの時間と労力を要 することである。しかし，近年の bacterial artificial chromosome（BAC）を用いた技術の開発により, HSV-1 ゲ ノムを丸ごとプラスミドに組み込んで扱うことが可能と なり，遺伝子の組換えが格段に容易となった ${ }^{912)}$.

\section{遺伝子組換え HSV-1 による 腫瘍細胞のターゲッティング}

HSV-1の複製能を腫瘍細胞に限定するためには, ゲノ 厶を操作して非必須遺伝子を 1 複数個除去あるいは不 活化すればよい19)． $\gamma 34.5$ 遺伝子は，病原性 (virulence) に関連した遺伝子である。正常細胞では通常，ウイルス

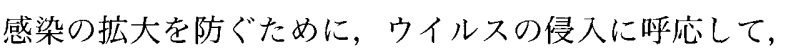
二本鎖 RNA 依存性 プロテインキナーゼ (doublestranded RNA-activated protein kinase; PKR)がリン酸化 され,最終的にウイルス蛋白の合成が遮断される， $\gamma 34.5$ 遺伝子産物は, このPKRに捛抗し, ウイルス蛋白の合 成を可能とする。 $\gamma 34.5$ 遺伝子は HSV-1 ゲ/ムに 2 コ ピーあり，その双方とも欠失させた遺伝子組換え HSV1 は, 正常細胞内では細胞の PKR を制御できないためウ イルス複製が不可能となるが，腫瘍細胞内では腫瘍細胞 のPKR が元来低下しているため, $\gamma 34.5$ 遺伝子がなくて も複製可能となる。

また，チミジンキナーゼ（thymidine kinase； tk）やリ ボヌクレオチド還元䤃素 (ribonucleotide reductase；RR) はウイルス DNA 合成に必須で，これらをコードするウ イルス遺伝子を除去・不活化すると, 変異 HSV-1 は分 裂が盛んで, $\mathrm{tk}$ 活性や $\mathrm{RR}$ 活性の上昇した腫䁑細胞での みウイルスの欠落酵素が補われてウイルス複製が可能と なる。 
Table 1 Representative recombinant oncolytic $\mathrm{HSV}-1$ vectors

\begin{tabular}{|c|c|c|c|c|}
\hline $\begin{array}{c}\text { Recombinant } \\
\text { HSV }-1\end{array}$ & Generation & $\begin{array}{l}\text { Parental } \\
\text { HSV-1 }\end{array}$ & Mutation & Inserted gene \\
\hline 1716 & 1 st & $17^{+}$ & $\begin{array}{c}759 \mathrm{bp} \text { deletion in both copies of } \\
\gamma 34.5\end{array}$ & \\
\hline R3616 & $1 \mathrm{st}$ & strain $\mathrm{F}$ & $\begin{array}{l}1000 \mathrm{bp} \text { deletion in both copies of } \\
\qquad 34.5\end{array}$ & \\
\hline R4009 & 1 st & strain $\mathrm{F}$ & $\begin{array}{c}\text { Stop codons in both copies of } \\
\gamma 34.5\end{array}$ & Stop codon \\
\hline NV1020（R7020） & 1 st & strain $\mathrm{F}$ & $\begin{array}{l}\text { Deletion of one copy of } \gamma 34.5 \text {, tk, } \\
\text { UL24. UL55, UL56, and IR }\end{array}$ & $\alpha 4$ (p)-TK, HSV-2gG, gJ, gD, gl \\
\hline NV1023 & 2nd & $\mathrm{F} / \mathrm{NV} 1020$ & Deletion of IR \& $\alpha 47$ & lacZ, HSV-2gG, gJ, gD, gl \\
\hline NV1034 & 2nd & $\mathrm{F} / \mathrm{NV} 1023$ & Deletion of IR \& $\alpha 47$ & $\begin{array}{c}\text { mGM-CSF, lacZ, HSV-2gG, gJ, } \\
\text { gD, gl }\end{array}$ \\
\hline NV1042 & 2nd & $\mathrm{F} / \mathrm{NV} 1023$ & Deletion of IR \& $\alpha 47$ & mlL12, lacZ, HSV-2gG, gJ, gD, gl \\
\hline G207 & 2nd & F/R3616 & $\begin{array}{c}1 \mathrm{~kb} \text { deletion in both copies of } \\
\gamma 34.5, \text { lacZ insertion in ICP6 } \\
\text { UL39 }\end{array}$ & lacZ \\
\hline $\mathrm{G} 47 \Delta$ & $3 \mathrm{rd}$ & $\mathrm{F} / \mathrm{G} 207$ & $\begin{array}{l}\text { Deletion in both copies of } \gamma 34.5 \\
\& \alpha 47 \text { lac } Z \text { insertion in ICP6 }\end{array}$ & $\operatorname{lac} Z$ \\
\hline $\mathrm{T}-01$ & $3 \mathrm{rd}$ & $\mathrm{G} 47 \Delta$ & $\begin{array}{c}\text { Deletion in both copies of } \gamma 34.5 \text {, } \\
\alpha 47, \& \text { ICP6 lacZ insertion in } \\
\text { ICP6 }\end{array}$ & lacZ \\
\hline
\end{tabular}

$\alpha 47$ 遺伝子産物は, 抗原提示関連トランスポーター (transporter associated with antigen presentation; TAP) を阻害することによって，ウイルス蛋白が細胞表面に提 示されることを防ぎ，ウイルスが宿主の免疫サーベイラ ンスから逃れる作用を有する. HSV-1 が感染すると $\alpha 47$ 遺伝子産物により宿主細胞の MHC クラス I 発現が低下 するが， $\alpha 47$ 遺伝子を欠失させると宿主細胞の MHC ク ラス I 発現レベルが維持されるため, 抗腫瘍効果惹起に 有利に衝くことが期待される。また， $\alpha 47$ 遺伝子と重な るUS11 遺伝子プロモーターが同時に欠失すると, US11 遺伝子発現時期が変化することに伴い, $\gamma 34.5$ 欠失 HSV-1の減弱したウイルス複製能を腫瘍細胞に限って 回復させ，殺腫瘍細胞効果を向上させる.

\section{各種遺伝子組換え HSV-1 の分類と概要（Table 1)}

\section{1 第一世代遗伝子組換え HSV-1}

ウイルスの非必須遺伝子を 1 つだけ変異させた増殖 型遺伝子組換え HSV-1, または単一の機序により腫瘍細 胞特異性を得ているものを第一世代と呼ぶ. 第一世代は, 一般に第二世代より複製能力を維持するが，病原性減弱 の不徹底や，変異が一箇所だけであるため相同組換えに よって野生型 HSV-1 へ自然に戻ってしまう可能性など があり，安全性の面で問題が残る，HSV1716 PN1020 （R7020）がこれに該当する.

\section{2 第二世代遺伝子組換え HSV-1}

$\gamma 34.5$ 遺伝子と DNA 合成酵素遺伝子など, 2 つの異な る機序を介して腫瘍特異的なウイルス複製を得た増殖型 遺伝子組換え HSV-1 を第二世代と呼ぶ。病原性が一層 弱められ, 野生型に戻る可能性がきわめて少なく, 安全 性が著明に改善した。 G207 は第二世代の代表で，米国 で再発悪性グリオーマを対象とした臨床試験が行われ た 17)19).

\section{3 第三世代遗伝子組換え HSV-1}

3 つの異なる機序を介して腫瘍特異性を持たせた増殖 型遺伝子組換え HSV-1 を第三世代と呼ぶ. G47 $\Delta$ は, G207 と同じ $\gamma 34.5$ 遺伝子欠失と ICP6 遺伝子 (RR) 変 異に加えて,さらに $\alpha 47$ 遺伝子およびそれと重なる US11 プロモータ一領域を欠失する ${ }^{26)}$. 最近, G47 $\Delta$ の ICP6 遺伝子の不活化変異を欠失変異に改良した T-01 も開発された，第三世代は，第二世代の安全性を保ちつ つ, ウイルス複製能と抗腫瘍効果が著しく向上した.

\section{4「武装」遺伝子組換え HSV-1}

増殖型 HSV-1 のゲノムに外来治療遺伝子（transgene） を直接組み込むと, 増殖型 HSV-1 そのものを増殖型の 治療遺伝子発現ベクターとして機能させることができ る. 現在, 治療効果をさらに高めるための外来治療遺伝 子を組み込んだウイルスの開発が精力的に進められてい 


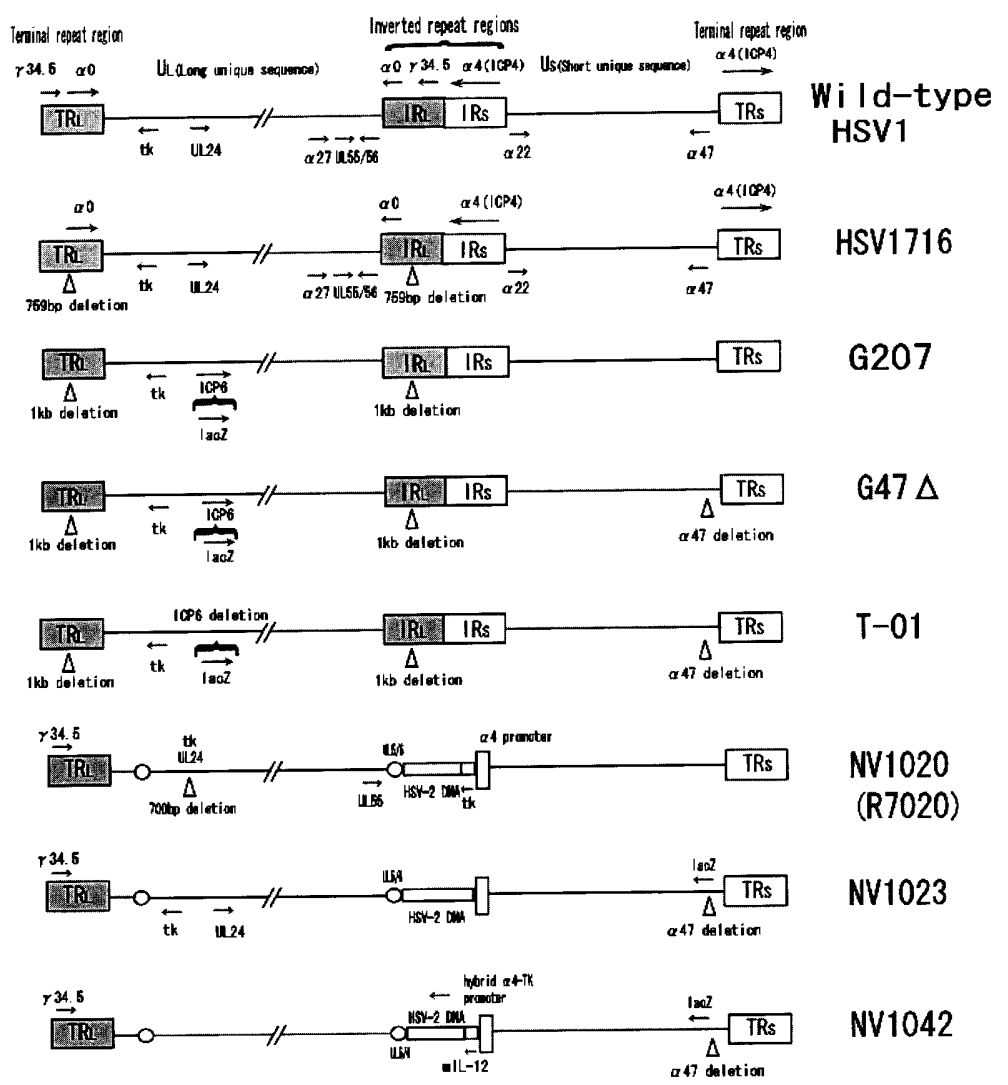

Fig. 2 HSV-1 structures and their representative recombinant oncolytic $\mathrm{HSV}-1$ vectors

る，例えば，NV1020（R7020）を少し修飾した NV1023 の基本骨格でマウス IL-12 を発現する NV1042（Fig. 2） は，ウイルスによる直接的な殺細胞作用に加えて，抗腫 瘍免疫の惹起と腫瘍血管新生の抑制効果を呈し，マウス IL-12 を発現しないNV1023に比べ抗腫煌効果を有意に 増強することが, 複数のマウス腫瘍モデルにおいて示さ 枕草28).

\section{5 臓器・腫瘍特異的プロモーターを利用した 遺伝子組換え HSV-1}

ある臟器, 腫佰に特異的に発現さ机る蛋白質の遺伝子 のプロモーターでウイルスの遗伝子を制御することによ り, その臟器や腫瘍においてのみウイルスが複製可能に なるか複製能が向上するように遺伝子操作した増殖型 HSV-1 である. 肝細胞に特異的なアルブミン ${ }^{21)}$ や分化 神経細胞に特異的なネスチンのプロモーター ${ }^{14) な と ゙ を ~}$ 利用したウイルスベクターが開発されている。

中間径フィラメントを構成する蛋白であるネスチンは グリオーマのマーカーの一つであるとされる。ネスチン は，神経細胞の発生の段階で発現されるが，成熟脳では 発現が抑制されており，腫瘍細胞などの増殖細胞中のみ
発現している，rQNestin34.5 は，ネスチンプロモーター により $\gamma 34.5$ をコントロールし， $\gamma 34.5$ を腫煌細胞の中 でのみ発現させ，腫瘍細胞のみでウイルスの複製能を向 上して抗腫瘍効果を発揮させるべくデザインされた HSV-1 ベクターである14).

\section{脳腫瘍に対する増死型遺伝子組換え HSV-1 の臨床試験}

臨床に応用された増殖型遺伝子組換え HSV-1 の代表 として，HSV1716，G207が挙げられる，HSV1716は， $\gamma 34.5$ 遺伝子のみを欠失した第一世代の増殖型 HSV-1 ベクターである (Fig. 2)。1990 年代後半, 英国のグルー プにより，再発悪性グリオーマに対する HSV1716 の第 I 相臨床試験が行われた。腫愓内に定位的に $10^{3}, 10^{4}$, $10^{5}$ プラーク形成単位 (plaque-forming units; pfu) の HSV1716 を 3 人ずつ投与が行われたが，どの患者におい ても脳炎などの副作用や潜在性 HSV-1 の再活性化など は認められず，安全性が確認された。またその 9 人の患 者のうち，投与 $14 \sim 24$ 力月後に拀いて 4 人の生存が確 認され, HSV1716の有効性も示唆された ${ }^{24)}$. 
また同グループは，あらかじめ HSV-1 の抗体值を測 定した 12 人の悪性グリオーマの患者に対して生検を兼 ねて,まず $10^{5} \mathrm{pfu} の \mathrm{HSV} 1716$ を定位的に投与した。その 4〜9 日後に腫瘍を切除し，その検体を調べたところ，10 人から HSV-1 DNA，2人より抗 HSV-1免疫染色で HSV1716 の複製が確認された。また，5人に血清 HSV一 1 抗体の陽転を認め, HSV-1 に対する免度反応が認めら れた。この試験において HSV-1 抗体保有の有無にかか わらず，毒性を惹起することなく，悪性脳腫瘍内で HSV1716 が複製することが示された23).

さらに同グループにより, 12 人の悪性グリオーマの患 者に対して,今度は腫瘍切除後の腫瘍腔壁に HSV1716 を 直接投与する臨床試験が行われた。術後，適応があれば 放射線㙩法，化学療法も行わ机た。術後 14 力月後の時 点で，画像上 10 人の患者において腫瘍の増大を認め, 術後 15 力月の時点で 3 人の生存が確認された ${ }^{10)}$

HSV1716 は, 弱毒化の程度が低く複製能を維持するた め, 少ないウイルス量で高い殺細胞効果が得られる可能 性がある一方で，毒性や野生型への復元（spontaneous reversion）の危険性が第二世代などに比べて高いため, 高い投与量を実施し得ない，その点，第二世代の G207 は元来脳腫愓治療用に開発され， $\gamma 34.5$ 遺伝子の欠失と lacZ 遺伝子挿入による ICP6 遺伝子 (RR) の不活化の二 重変異が施されて, 安全性が格段に改善されている (Fig. $2)^{20)}$ ．再発悪性グリオーマ患者 21 名を対象に米国で第 I 相臨床試験が行われた。ウイルス投与量は, $1 \times 10^{6}$ から $3 \times 10^{9} \mathrm{pfu}$ まで 3 名ずつ段階的に増量した. 造影 CT の増 強部位に定位的に腫瘍内投与されたところ，どの患者に おいてもグレード $3 ， 4$ 相当の重篤な有害事象はみられ なかった ${ }^{17)}$ 。この最高投与量は，英国で臨床試験が行わ れた HSV1716 の最高 $10^{5} \mathrm{pfu}$ と比べ 3 万倍で, G207 の安 全性の高さが推測される。効果については，6例 (29\%) に Karnofsky スコアの一時的な改善がみられた，MRIに て腫瘍体積の経時的評価を行ったところ，投与前と比較 し投与 1 力月後において 20 例中 6 例に腫瘍の縮小を認 めたが，死亡した 1 例を除いた全例にて再増大を認め た。生検あるいは再摘出術で得られた腫瘍組織 7 例中 2 例で，PCRにて G207の DNA が検出された．剖検 5 例 中 3 例にて腫場が脳の一領域に限局し, 神経膠芽腫に通 常みられるような腫瘍細胞の周囲脳組織への著明な浸潤 を認めなかった ${ }^{17)}$ 。第 Ib 相試験では，脳腫瘍摘出後，摘 出胿壁に G207 を直接投与する方法が採られた，放射線 治療や化学療法と G207 を併用した臨床試験が米国で計 画されている.

\section{ウイルス療法の展望}

ウイルス療法の臨床試験はまだ黎明期であり，抗腫瘍 効果を最適化するプロトコールの開発や腫瘍内のウイル ス複製のイメージング評価の確立などまだ課題も多い. In vivo におけるウイルス複製の評価は，非侵襲的にルシ フェラーゼを用いてイメージングすることがすでにマウ スでは実用化されている，さらに，最近 $\mathrm{tk}$ の選択的基質 である

5-iodo-2'-fluoro-1- $\beta$-D-arabinofuranosyl-uracil （FIAU）を用いた PET imaging において，HSV-1の tk 遺伝子の発現レベルを非侵襲的にモニターすることが可 能であることが報告された。 Bennett ら $^{2)}$ は, 大腸癌細胞 株 HCT8 のラット側腹部 $0.5 \mathrm{~cm}$ 径の皮下腫瘍内に HSV-1 ベクターを投与し，その 8 時間, 48 時間後に ${ }^{124} \mathrm{I}-$ labeled FIAU を投与し，さらにそれぞれその 3 日後に PET を施行した。その結果， $1 \times 10^{7} \mathrm{pfu}$ の低投与量でも FIAU の集積を検出可能であり, $0.5 \log$ のウイルス投与量 の差を集積度の違いにより検出できた。またウイルス投 与 8 時間後よりも 48 時間後に FIAUを投与したほうが 集積が強かった。このことから，HSV-1の $t k$ 遺伝子発 現レベルをPET で検出することにより，増殖型 HSV-1 ベクターの複製の程度と分布を非侵襲的に体外から確認 できることを示した，ヒトにおいても，ウイルス療法の 効果を PETにて判定できることが今後期待される.

また，ウイルス療法と他の補助療法との併用の有効性 が指摘されている ${ }^{6)}$ Advani ら ${ }^{11}$ は, ヌードマウスにおけ る U87 MG の皮下腫瘍モデルにおいて，R3616 ウイルス 治療および放射線の併用療法とそれぞれの単独治療との 抗腫瘍効果の比較検討を行った。 ウイルス投与の 1 日後 に $20 \mathrm{~Gy}$ ，そして 2 日後に $25 \mathrm{~Gy}$ という分割照射放射線 の併用療法は，R3616 ウイルス単独治療と比べ，ウイル スの複製を 2 ～倍に増加させることにより抗腫瘍効果 を相乗的に増強し，著明な延命効果がみられた。また， ヌードマウスの扁平上皮癌細胞株皮下腫瘍モデルにおけ る G207 ウイルス治療と放射線療法 (5 Gy の 1 回照射)の 併用療法 ${ }^{15)}$ やヌードマウスの U87 MG の脳腫愓モデル におけるR3616 ウイルス治療と分割放射線療法 (5 Gy を 1 日おきに計 6 回, Total $30 \mathrm{~Gy}$ ）の併用療法 ${ }^{5}$ を検証 した異なる腫瘍モデルにおいても，同様の結果が観察さ れている，G207に関しては，放射線によるDNAの損傷 により，腫瘍細胞の ribonucleotide reductase（RR）およ びウイルスの複製に直接関与していると考えられてい る GADD34 蛋白の up-regulation がウイルス複製增強の

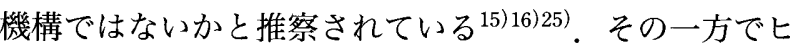


ト前立腺癌細胞株 LNCap をヌードマウスに, またマウス 前立腺癌細胞株 TRAMP を C57BL/6 マウスに植えたそ れぞれの皮下腫瘍モデルにおいて, G207 と放射線の同時 投与が行われたが，その相乗効果はみられなかった ${ }^{13)}$. このように, 放射線療法との併用の相乗効果に関しては, 依然 controversial であるが, 放射線照射の夕イミング, 線 量などの条件が最適化できれば，将来臨床においても， ウイルス治療と放射線療法の併用による治療成績の向上 が期待できる。

化学療法についても, マウスの非小細胞癌細胞株 $\mathrm{NCI}-\mathrm{H} 460$ の皮下腫瘍に対して, HSV-1716の投与 1 日 後にマイトマイシン C の静注を施行したところ, 単独治 療と比べ, 有意に腫瘍縮小効果を認めたという27)。また, マウスの胃癌モデルにおいて, マイトマイシン C の併用 が腫瘍細胞の GADD34 を誘導し, G207 の抗腫瘍効果を 著明に増強したと報告されている4）

これら従来の補助療法が, ウイルス療法と併用できる のみでなく, 相乗的抗腫瘍効果が期待できることは, 実 際の臨床においては特に重要な点であるが, 現時点では まだ報告は少数であり, 今後の研究課題となっている. 動物実験と臨床試験を経て, 適切なプロトコールが確立 されることが望まれる。

\section{おわりに}

ウイルス療法は, ウイルスが腫瘍細胞内で選択的に複 製して直接細胞を破壊することが基本であり, 腫瘍細胞 に共通した性質を利用するため腫瘍の種類を問わないこ と, 患者の年齢, 性別などによる適用制限が少ないこと, 放射線療法, 化学療法, 免疫療法など他の補助療法との 併用で相乗効果が期待できること, 増殖型治療遺伝子発 現ベクターとして遺伝子分配も可能であることなど多く の優れた点を有する。

一方で, 増殖型ウイルスとはいえ, 臨床においてすべ ての腫瘍細胞に感染をいき渡らせることは困難であり， より効果的なウイルス投与法と抗腫瘍効果の増強法を開 発していく必要がある. 静脈内投与など非観血的投与法 で効果的なウイルス療法を行うのが理想だが，血液によ る希釈や, 血管壁への吸着, 肝蔵での補足などの問題に 加え, 特に脳腫瘍治療においては脳血液関門 (blood brain barrier；BBB）という障壁が存在し，血管内投与法の実 用化にはなお工夫を要する。 ラットでは増殖型 HSV-1 を頸動脈内に投与する際に, cyclophosphamide やマニ トールを予め投与しておくと脳腫瘍へのウイルス分配が 格段に向上することが観察されている11).
ウイルス療法は，より効果的で安全な治療遺伝子発現 型ウイルスベクターの開発や他の補助療法との併用など 今後大きな発展性を有している. 新たな delivery system の開発により静脈内投与法や頻回反復投与などが確立さ れれば, ウイルス療法が近い将来脳腫瘍補助療法の first line therapy となることが期待される.

\section{文 献}

1) Advani SJ, Sibley GS, Song PY, Hallahan DE, Kataoka Y, Roizman B, Weichselbaum RR: Enhancement of replication of genetically engineered herpes simplex viruses by ionizing radiation: A new paradigm for destruction of therapeutically intractable tumors. Gene Ther 5:160-165, 1998.

2) Bennett JJ, Tjuvajev J, Johnson P, Doubrovin M, Akhurst T, Malholtra S, Hackman T, Balatoni J, Finn R, Larson SM, Federoff $\mathrm{H}$, Blasberg R, Fong Y: Positron emission tomography imaging for herpes virus infection: Implications for oncolytic viral treatments of cancer. Nat Med 7:859863, 2001.

3) Bennett JJ, Malhotra S, Wong RJ, Delman K, Zager J, StLouis M, Johnson P, Fong Y: Interleukin 12 secretion enhances antitumor efficacy of oncolytic herpes simplex viral therapy for colorectal cancer. Ann Surg 233: 819$826,2001$.

4) Bennett JJ, Adusumilli P, Petrowsky H, Burt BM, Roberts G, Delman KA, Zager JS, Chou TC, Fong Y: Up-regulation of GADD34 mediates the synergistic anticancer activity of mitomycin $\mathrm{C}$ and a $\gamma_{1} 34.5$ deleted oncolytic herpes virus (G207). FASEBJ 18:1001-1003, 2004.

5) Bradley JD, Kataoka Y, Advani S, Chung SM, Arani RB, Gillespie GY, Whitley RJ, Markert JM, Roizman B, Weichselbaum RR: Ionizing radiation improves survival in mice bearing intracranial high-grade gliomas injected with genetically modified herpes simplex virus. Clin Cancer Res 5: 1517-1522, 1999.

6) Chahlavi A, Todo T, Martuza RL, Rabkin SD: Replicationcompetent herpes simplex virus vector G207 and cisplatin combination therapy for head and neck squamous cell carcinoma. Neoplasia 1:162-169, 1999.

7) Dock G: The influence of complicating diseases upon leukaemia. Am J Med Sci 127: 563-592, 1904.

8）藤原大美: 腫瘍免疫学, 第 2 版. 東京, 中外医学社, 2003.

9) Fukuhara H, Ino Y, Kuroda T, Martuza RL, Todo T : Triple gene-deleted oncolytic herpes simplex virus vector double-armed with IL-18 and soluble B7-1 constructed by bacterial artificial chromosome-mediated system. Cancer Res 65: 10663-10668, 2005.

10) Harrow S, Papanastassiou V, Harland J, Mabbs R, Petty R, Fraser M, Hadley D, Patterson J, Brown SM, Rampling R: HSV1716 injection into the brain adjacent to tumour following surgical resection of high-grade glioma: Safety data and long-term survival. Gene Ther 11: 1648-1658, 2004.

11) Ikeda $K$, Ichikawa $T$, Wakimoto $H$, Silver JS, Deisboeck TS, Finkelstein D, Harsh GR 4th, Louis DN, Bartus RT, Hochberg FH, Chiocca EA: Oncolytic virus therapy of multiple tumors in the brain requires suppression of innate and elicited antiviral responses. Nat Med 5:881-887, 1999.

12) Ino $Y$, Saeki $Y$, Fukuhara $H$, Todo $T$ : Triple combination of 
oncolytic HSV-1 vectors "armed" with interleukin 12 , interleukin 18 or soluble B7-1 results in enhanced antitumor efficacy. Clin Cancer Res (in press).

13) Jorgensen TJ, Katz S, Wittmack EK, Varghese S, Todo T, Rabkin SD, Martuza RL: Ionizing radiation does not alter the antitumor activity of herpes simplex virus vector G207 in subcutaneous tumor models of human and murine prostate cancer. Neoplasia $3: 451-456,2001$.

14) Kambara $H$, Okano $H$, Chiocca EA, Saeki $Y$ : An oncolytic HSV-1 mutant expressing ICP34.5 under control of a nestin promoter increases survival of animals even when symptomatic from a brain tumor. Cancer Res 65:2832$2839,2005$.

15) Kim SH, Wong RJ, Kooby DA, Carew JF, Adusumilli PS, Patel SG, Shah JP, Fong Y: Combination of mutated herpes simplex virus type 1 (G207 virus) with radiation for the treatment of squamous cell carcinoma of the head and neck. Eur J Cancer 41: 313-322, 2005.

16) Kuo ML, Kinsella TJ : Expression of ribonucleotide reductase after ionizing radiation in human cervical carcinoma cells. Cancer Res $58: 2245-2252,1998$.

17) Markert JM, Medlock MD, Rabkin SD, Gillespie GY, Todo T, Hunter WD, Palmer CA, Feigenbaum F, Tornatore C, Tufaro F, Martuza RL: Conditionally-replicating herpes simplex virus mutant, G207 for the treatment of malignant glioma: Results of a phase I trial. Gene Ther $7: 867-874$, 2000.

18) Martuza RL, Malick A, Markert JM, Ruffner KL, Coen DM : Experimental therapy of human glioma by means of a genetically engineered virus mutant. Science 252:854856, 1991.

19) Martuza RL: Conditionally replicating herpes vectors for cancer therapy. J Clin Invest $105: 841-846,2000$.

20) Mineta T, Rabkin SD, Yazaki T, Hunter WD, Martuza RL: Attenuated multi-mutated herpes simplex virus -1 for the treatment of malignant gliomas. Nat Med 1:938-943,
1995.

21) Miyatake S: Gene therapy using tissue-specific replication competent HSV. Hum Cell 15: 130-137, 2002.

22) Moore AE: Effects of viruses on tumors. Ann Rev Microbiol 8: 393-410, 1954.

23) Papanastassiou V, Rampling R, Fraser M, Petty R, Hadley D, Nicoll J, Harland J, Mabbs R, Brown M: The potential for efficacy of the modified (ICP $34.5^{-}$) herpes simplex virus HSV1716 following intratumoural injection into human malignant glioma: A proof of principle study. Gene Ther 9:398-406, 2002.

24) Rampling R, Cruickshank G, Papanastassiou V, Nicoll J, Hadley D, Brennan D, Petty R, MacLean A, Harland J, McKie E, Mabbs R, Brown M: Toxicity evaluation of replication-competent herpes simplex virus (ICP 34.5 null mutant 1716) in patients with recurrent malignant glioma. Gene Ther 7:859-866, 2000.

25) Stanziale SF, Petrowsky H, Joe JK, Roberts GD, Zager JS, Gusani NJ, Ben-Porat L, Gonen M, Fong Y : Ionizing radiation potentiates the antitumor efficacy of oncolytic herpes simplex virus $\mathrm{G} 207$ by upregulating ribonucleotide reductase. Surgery 132: 353-359, 2002.

26) Todo T, Martuza RL, Rabkin SD, Johnson PA: Oncolytic herpes simplex virus vector with enhanced MHC class I presentation and tumor cell killing. Proc Natl Acad Sci USA 98: 6396-6401, 2001.

27) Toyoizumi T, Mick R, Abbas AE, Kang EH, Kaiser LR, Molnar-Kimber KL: Combined therapy with chemotherapeutic agents and herpes simplex virus type 1 ICP34.5 mutant (HSV-1716) in human non-small cell lung cancer. Hum Gene Ther 10: 3013-3029, 1999.

28) Wong RJ, Chan MK, Yu Z, Kim TH, Bhargava A, Stiles BM, Horsburgh BC, Shah JP, Ghossein RA, Singh B, Fong $\mathrm{Y}$ : Effective intravenous therapy of murine pulmonary metastases with an oncolytic herpes virus expressing interleukin 12. Clin Cancer Res 10:251-259, 2004.

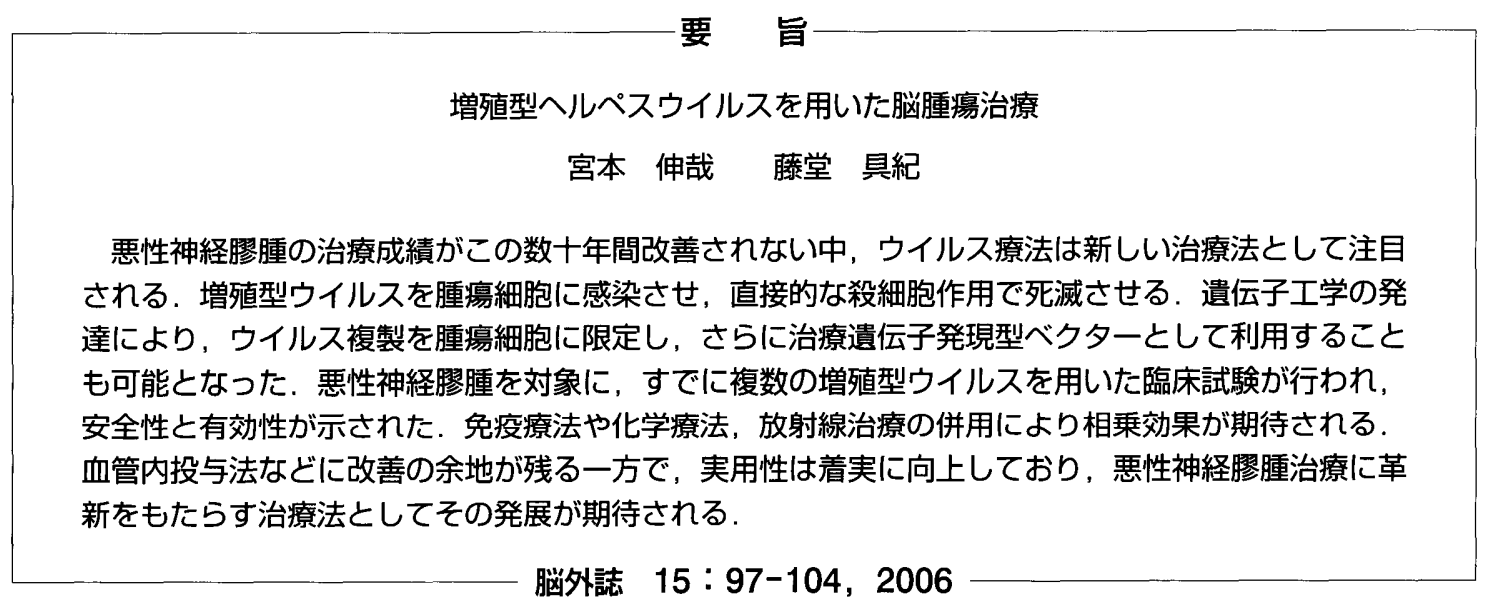

